\title{
Diversity is Strategy: The Effect of R\&D Team Diversity on Innovative Performance
}

\section{Marian Garcia Martinez ${ }^{1}$}

Kent Business School, University of Kent, UK

m.garcia@kent.ac.uk

Ferdaous Zouaghi

Public University of Navarra, Pamplona, Spain

ferdaous.zouaghi@unavarra.es

Teresa Garcia Marco

Public University of Navarra, Pamplona, Spain

tgmarco@unavarra.es

This is the peer reviewed version of the following article: Garcia Martinez, M., Zouaghi, F. and Garcia Marco, T. (2017), Diversity is strategy: the effect of R\&D team diversity on innovative performance. R\&D Management, 47: 311-329. doi:10.1111/radm.12244 which has been published in final form at https://doi.org/10.1111/radm.12244. This article may be used for non-commercial purposes in accordance with Wiley Terms and Conditions for Use of Self-Archived Versions.

\footnotetext{
${ }^{1}$ Corresponding author
} 


\title{
Diversity is Strategy: The Effect of R\&D Team Diversity on Innovative Performance
}

\begin{abstract}
Diversity in the workplace has attracted significant interest in organisations that want to attract and retain talented employees. Breakthrough innovation requires a wider knowledge base and organisations increasingly rely on multidisciplinary R\&D teams to identify scientific developments that bridge gaps and reduce time to market. However, research on the performance implications of R\&D team diversity remains limited and the empirical evidence inconsistent. This paper investigates the impact of surface and deep-level diversity on R\&D teams' innovative performance and how diversity dimensions interact to drive innovation. We find supportive evidence that R\&D team characteristics influence innovation outcomes, confirming our hypothesising that diversity is a valuable strategy for an organisation to pursue as it provides greater cognitive ability. Each diversity facet however has its own distinct effects depending on the novelty of innovation and industry. Yet, diversity is not solely positive and excessive heterogeneity could be detrimental to R\&D team performance. Our findings suggest that high diversity in gender or skills in cognitively diverse teams might be negative attributes to take into consideration. Senior managers and organisations should therefore consider the appropriate mix of capabilities to benefit from creativity in diverse R\&D teams and avoid possible conflict and distrust associated with diversity.
\end{abstract}




\section{Introduction}

Diversity is often described as a 'two-edged sword' Horwitz and Horwitz, 2007) or a mixed blessing Williams and O'Reilly, 1998 for its contradictory influence on organisational outcomes. Teams with diverse backgrounds bring together a wider spectrum of taskrelevant knowledge, experience and perspectives that are distinct and non-redundant van Knippenberg et al., 2004, which can be combined in new ways, leading to positive cognitive effects (Page, 2007). Research even suggests that group heterogeneity is more important than individual ability e.g., Hong and Page, 2004. On the other hand, diversity can reduce team performance by negatively affecting cohesion, decision-making quality and members commitment to the group Goodstein et al., 1994, Mintzberg, 1983).

This paper examines the 'value in diversity' hypothesis (Cox et al., 1991) in innovation, an area still largely underdeveloped in organisational innovation research Van der Vegt and Janssen, 2003, Talke et al., 2010. Despite a dramatic increase in the organisational use of multidisciplinary teams for innovation, our understanding of the influence of diversity in innovation teams' processes and outcomes remains limited and the empirical evidence inconsistent Roberge and van Dick, 2010. This study aims to address this research gap by differentiating among types of diversity (i.e., gender, skills and education diversity - facets of surface and deep-level diversity) and investigating their main effects on innovation performance, hypothesising that the value in R\&D team diversity emerges from individuals' unique attributes that bring different task-relevant knowledge and perspectives to the group van Knippenberg et al., 2004. Groups that consider a wider range of possible alternatives generate more creative, novel solutions Sutton, 2007. Further, we examine how diversity dimensions interact to drive innovation, responding to calls for a more holistic view of the overall potential influence of different facets of diversity (Shore et al., 2009).

This paper contributes to the literature in several distinct ways. First, it makes a theoretical contribution to organisational innovation research by considering the influence of multiple dimensions of diversity on innovation novelty - incremental and radical innovation. Downs and Mohr (1976 challenged the idea of a single theory of innovation and argued that each form of innovation could be explained by different predictive variables. Simons et al. (1999) demonstrate the utility of treating diversity as a multifaceted construct whose different 
facets interact with team processes to shape organisational performance in different ways. Second, we contribute to human capital diversity and innovation research by considering the interaction effects between diversity criteria and the resulting impact on innovative performance. Faultline research shows how including individuals' multiple diversity characteristics provides greater explanatory power regarding the overall influence of diversity on team performance (Lau and Murnighan, 2005). Third, we contend that the industry context can condition the effect of group diversity on performance Joshi and Roh, 2009. Human resources and employees skills are key strategic assets in service innovation Gallouj and Weinstein, 1997 compared to formalised R\&D activities in manufacturing industries (Castellacci, 2008). Hence, we argue that due to differences in innovation processes and tasks, the dynamics of R\&D team diversity may differ depending on the industry setting.

The rest of the paper is structured as follows. Section 2 establishes the theoretical framework and presents the research hypotheses. Section 3 details the research design and methods and Section 4 presents the results of the empirical test. In Section 5, we discuss our main findings and elaborate on their theoretical and managerial implications and present a future research agenda on R\&D team diversity, which takes into account the study's limitations.

\section{Theoretical Background and Hypotheses}

\subsection{R\&D Teams Diversity in Innovation}

Diversity studies have examined group heterogeneity from two different theoretical perspectives: surface and deep-level diversity (Jackson et al., 1995). Harrison et al. (1998, p.97) defined surface-level diversity as 'differences among group members in overt, biological characteristics that are typically reflected in physical features'. Groups are kept together by the perceived similarities or dissimilarities of their members' demographic characteristics (e.g., age, gender, and race/ethnicity) Tajfel, 1978. Surface-level diversity, however, generates an instant sense of dissimilarity among team members, which preclude them from forming closer relationships Mehra et al., 1998, Gibbons and Olk, 2003 and is likely to hamper social interaction and communication (Jehn et al., 1999). 
Deep-level diversity refers to differences among group members' psychological characteristics, such as cognitive abilities, attitudes, values, knowledge and skills Harrison et al., 2002). These attributes take time to manifest themselves as team members need clues from their interactions with each other to become aware of them. Compared to homogeneous groups, cognitively diverse teams are superior with regard to the prerequisites to innovation: greater absorptive capabilities to integrate new knowledge and apply it to generate new ideas Cohen and Levinthal, 1990; higher requisite variety so they can refer to their internal knowledge and expertise to solve problems Nonaka and Takeuchi, 1995, and higher network variety to access an external diverse knowledge pool Katz and Tushman, 1979. Further, cognitively diverse groups are less prone to groupthink Janis, 1972).

A key question in innovation studies is how to maintain cohesion in cognitively diverse groups. In contrast to theories of social categorization (Turner et al., 1987), the interpersonal congruence approach Ely and Thomas, 2001) suggests that team members can achieve harmonious and effective work processes by expressing rather than suppressing the attributes that make them unique. Trying to address this contradiction, Bernthal and Insko (1993) distinguish between social-emotional and task-oriented cohesion and argue that that the latter can offset the former by promoting a strong analytical orientation in information gathering and analysis, greater task focus, and higher attraction to work in group tasks. This paper investigates the impact of surface and deep-level diversity on innovative performance. In addition, interaction phenomena of diversity variables are considered to determine the overall effects of having social categorically diverse yet informational heterogeneous R\&D teams. Our hypothesised model is depicted in Figure 1.

\subsection{Gender Diversity}

The diversity literature offers inconsistent results regarding the relationship between gender diversity and performance outcomes. Some scholars have reported that genderheterogeneous groups tend to exhibit increased conflict, low cohesion and increased turnover (Milliken and Martins, 1996). Such findings have often been explained by social identity theory in combination with self-categorisation theory (Turner et al., 1987. These theories suggest that greater diversity in salient, demographic features, such as gender, 
causes group members to employ divisive categorisations that often yield negative consequences. On the other hand, several scholars have found that gender diversity promotes innovation, creativity Øøstergaard et al., 2011, Díaz-García et al., 2013)| Fernández Sastre, 2015, and productivity (Wood, 1987), with no evidence for increased conflict O'Reilly et al., 1998, Pelled et al., 1999). Such positive effects of diversity have often been explained in terms of the value-in-diversity hypothesis (Cox et al., 1991, which argues that differences among group members result in increased information availability, perspectives, knowledge and skills Ely and Thomas, 2001, Jehn et al., 1999. With respect to gender diversity, in particular, diversity studies refer to the superior performance of mixed teams resulting from different thinking styles and behavioural modes that can complement each other in R\&D projects \begin{tabular}{|l|l|l|}
\hline Fenwick and Neal, 2001) & Faems and Subramanian, 2013. \\
\hline
\end{tabular}

The management literature observes that having women within teams improves soft management skills and decision making processes, and enhances creativity and innovation

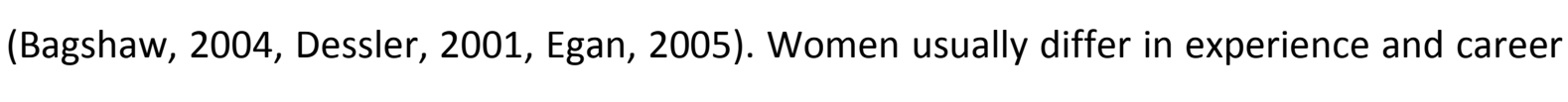
trajectories from their male counterparts (Daily et al., 2003, but rather than equating to less experience, it suggests highly diverse human and social capital backgrounds, which might contribute to enhanced performance Singh et al., 2008. Further, gender diversity may also improve the team's external relationships, allowing group members to acquire knowledge and ideas through collaborations with external groups Joshi and Jackson, 2003, leading to greater innovation capabilities. Therefore, we hypothesise:

H1: Gender diversity is positively associated to (a) incremental and (b) radical innovation performance.

\subsection{Skills Diversity}

Skills diversity refers to the portfolio of researchers, technicians and supporting staff in R\&D teams OECD, 2002. Skills diversity usually emerges from dealing with different issues and facing diverse sets of conditions, resulting in better abilities to find, integrate and use new knowledge and later developmental opportunities Yang et al., 2009, Østergaard et al., 2011. It also affects how problems are formulated and what types of solutions are generated Sollner, 2010. Since innovation is an iterative process Lundvall, 1988, which requires diverse knowledge bases among those involved in creativity and innovation, 
knowledge diversity should generally positively affect firm innovation performance (Dunbar, 1995, Dunbar, 1997). Innovation studies show that R\&D teams gain significant personal experience from interactions among team members with different knowledge bases and skill sets Chandrasekaran and Linderman, 2015, increasing team members' ability to engage in complex, non-routine tasks (Lin, 2014). Hence, we expect skills diversity to be positively related to a firm's propensity to innovate.

H2: Skills diversity is positively associated to (a) incremental and (b) radical innovation performance.

\subsection{Education Diversity}

Similarly to other types of knowledge diversity, diversity studies have shown inconclusive results regarding the impact of education diversity on performance outcomes. By using their interpersonal dissimilarities, educationally diverse teams are better prepared to solve complex problems because the internal pool of knowledge available to them and the integration of different perspectives and opinions, encouraging inspiring discussions, mutual learning, and more novel, creative solutions Jackson and Joshi, 2004, Faems and Subramanian, 2013. Similarly, Cohen and Levinthal (1990) argue that individuals' absorptive capacity and problem-solving ability are likely to increase with variety in knowledge structures based on their educational background. Research has reported the influence of education diversity in situations where teams engage in complex cognitive tasks with multiple possible solutions Jackson, 1996, Milliken and Martins, 1996. However, according to social identity theory, education diversity is likely to increase the communication and coordination costs of integrating available knowledge or coordinating the innovation process (Dahlin et al., 2005, Wittenbaum and Stasser, 1996).

Bolli et al. (2015) argue that the benefits of stimulating creativity and the costs of coordination and communication from high cognitive distances might differ along the innovation process. Several scholars suggest that the creativity benefits are more relevant for the generation of new knowledge or the invention of new products while coordination and communication costs become more important in commercialisation and marketing activities e.g., Atuahene-Gima and Evangelista, 2000. We hypothesise that education 
diversity broadens and deepens the cognitive and mental maps of R\&D teams, leading to superior innovative performance.

H3: Education diversity is positively associated to (a) incremental and (b) radical innovation performance.

\subsection{Interaction effects between surface and deep-level diversity}

Researchers argue that considering single diversity criteria only provides limited insight on the influence of diversity on R\&D teams' performance and have called for more complex theoretical conceptualizations of diversity Harrison and Klein, 2007, van Knippenberg and Schippers, 2007). The central premise of alignment theories is that multiple characteristics of individual differences are likely to be salient at the same time, and their influence must therefore be considered simultaneously Bezrukova et al., 2007. Lau and Murnighan (1998 introduced the group 'faultline' concept to describe the configuration of teams members' demographic attributes. The more highly correlated team member attributes are, the stronger faultlines will be, increasing the likelihood that homogenous subgroups will develop Lau and Murnighan, 2005, Pelled et al., 1999). Empirical studies have shown that groups with strong faultlines are more likely to experience a variety of negative consequences, including greater conflict and decreased performance (for a review of group faultlines refer to Thatcher and Patel, 2012, Thatcher and Patel, 2011. Increasingly, however, faultline scholars acknowledge that faultlines may not necessarily negatively affect team functioning (e.g., Bezrukova et al., 2009,Molleman, 2005).

Diverse R\&D teams are built to provide high task cohesion and are characterized by heterogeneous knowledge, skills, abilities, and attitudes Bowers et al., 2000. Thus, informational and social category attributes co-occur in members and thus in groups (Jehn et al., 2008. Faultline theorising proposes differential effects of particular types of faultlines; however, most empirical studies have focused on the consequences of strength of faultlines in general (e.g., Lau and Murnighan, 2005, Rico et al., 2012. In the present study, we account for the multiple faultlines that may be present within R\&D teams and evaluate the differential effects on firm innovation performance. 
Grounded on the cognitive resource perspective, we hypothesise that task-related diversity (education and skills diversity) positively impacts group performance since members can access a wider array of opinions, skills and perspectives Horwitz and Horwitz, 2007. Group members in informational diverse groups will engage in debates about divergent view points and discuss their disagreements over group tasks, which stimulates task conflict Jehn et al., 1997). Task conflict is considered an important driver of teams' creativity and innovative behaviour Woodman et al., 1993. Task-related faultlines may operate as 'healthy divides' that stimulate effective decision-making processes and improve group performance Gibson and Vermeulen, 2003 by utilising members' cognitive resources. Information-based subgroups may function as cohesive groups of individuals whose shared knowledge and expertise facilitates receiving support from each other. As a results, groups may more readily express opinions and share knowledge with members of other subgroups \begin{tabular}{l}
\begin{tabular}{l} 
Nemeth and Goncalo, 2005; such exchanges encourage creativity and healthy debate \\
\hline Bezrukova et al., 2009, [Carton and Cummings, 2012,
\end{tabular} Gibson and Vermeulen, 2003, \\
promoting team learning and performance (Gibson and Vermeulen, 2003, |van Knippenberg \\
\hline
\end{tabular} et al., 2004. Thus, we argue that the interaction of information diversity dimensions is positively related to innovation performance.

H4: Skills diversity positively moderates the relationship between R\&D team members' education diversity and innovative performance. The positive association between education diversity and innovative performance increases as skills diversity increases.

Faultlines are highly context dependent and might be beneficial under the 'right' conditions Williams and O'Reilly, 1998. Social-category faultlines may not always elicit intergroup bias to the same extent; some contexts may reduce the salience of social identities and help alleviate the problems associated with faultlines Jehn and Bezrukova., 2010. Innovation involves tasks requiring frequent inter-group interactions where R\&D teams benefit and value differing viewpoints, backgrounds, and insights. We argue that the innovation context favours social integration and is less conducive to social categorization, in-group bias, and intergroup conflict Gonzalez and DeNisi, 2009. Gender diversity improves the results of interactive decisions Fenwick and Neal, 2001), broadens the perspective, and contributes to better social relations and an open work climate and debate Nielsen and Huse, 2010a, 
Nielsen and Huse, 2010b. Hence, innovation provides a context in which demographic faultlines can be a 'healthy divide' (Gibson and Vermeulen, 2003, Iseke et al., 2015).

H5: Gender diversity positively moderates the relationship between R\&D team members' education diversity and innovative performance. The positive association between education diversity and innovative performance increases as gender diversity increases.

H6: Gender diversity positively moderates the relationship between R\&D team members' skills diversity and innovative performance. The positive association between skills diversity and innovative performance increases as gender diversity increases.

\section{Insert Figure 1 here}

\section{Methodology}

\subsection{Data and Sample}

The data for the quantitative analysis has been drawn from the Technological Innovation Panel (PITEC), which is a statistical instrument for studying innovation activities of Spanish companies over time. The database contains panel data for more than 12,000 firms since 2003 and offers key advantages to the study of diversity in R\&D teams compared, for instance, to the CIS survey where diversity is not covered. First, it contains detailed information on firms' R\&D activities and more importantly classifies R\&D staff in terms of gender, education and skills, all critical variables to diversity research. Secondly, PITEC is designed as a panel data survey so we overcome estimation problems related to the simultaneity between innovation inputs and outputs, by lagging independent variables Mairesse and Mohnen, 2010. Lagged-variable models have superior predictive validity, especially when measuring innovation outcomes Bradley et al., 2010 Laursen and Salter, 2006. In addition, it mitigates common method bias concerns since the time occurrence of predictors is well defined before outcomes are observed (Podsakoff et al., 2003,

The study was conducted using information on firms' innovation activities and employment characteristics for the years 2005-2012, including both manufacturing and service firms since the literature reports industry differences in terms of innovation processes and tasks (e.g., Sirilli and Evangelista, 1998, Evangelista, 2000. For the purpose of the present 
research, the dataset was confined to companies with a positive expenditure in internal $R \& D$ for at least one year during the studied period ${ }^{2}$. Table 1 shows the main features of the sample.

\subsection{Measures}

\section{Insert Table 1 here}

\subsubsection{Dependent variable}

Innovative performance is the dependent variable of the model measured as the percentage of the firm's total sales from innovations Hitt et al., 1996. Consistent with CIS-based studies (e.g., Laursen and Salter, 2006, Sofka and Grimpe, 2010, we distinguish between incremental and radical innovation depending on their newness to the company or the market place. Radical innovation is measured as the percentage of the firm's total sales from innovations new to the market in the last 2 years. Incremental innovation is defined as the percentage of the firm's total sales from innovations new to the firm in the last 2 years. This lag ensures that sufficient time has elapsed since the introduction of innovations and their performance evaluation Langerak et al., 2008. Past studies have shown that this selfreport subjective performance measure is reliable and correlates highly with other objective indicators of innovation performance (Hagedoorn and Cloodt, 2003).

\subsubsection{Independent variables}

$R \& D$ team diversity is defined as the distribution of differences among R\&D team members of the firm with respect to a common attribute Harrison and Klein, 2007). In line with team diversity studies using categorical diversity attributes, we use Blau's 1977 index of heterogeneity:

$D=1-\sum_{i=1}^{k} p_{i}^{2}$

where $k$ represents the total number of categories of a variable, and $p_{i}$ is the proportion of $R \& D$ team members who fall in category $k$. The minimum value of 0 occurs when all $R \& D$

\footnotetext{
${ }^{2} R \& D$ employment data is only available for internal R\&D performers.
} 
team members fall within the same category and there is no variety (e.g., all R\&D team members are female). The greater the distribution of characteristics across categories, the higher the diversity index is.

We included three diversity measures: gender, skills and education. Since there are only two gender categories (male and female), Blau's gender diversity index can take on values ranging from 0 (when a R\&D team is dominated by a single gender) to 0.5 (when there is a balanced number of men and women in the R\&D team). The categorisation of skills was based on three different job functions related to the expertise of R\&D team members: 1 ) researchers, 2) technicians, and 3) supporting staff (OECD, 2002). Blau's index for skills diversity can vary from 0 (when there is only one skills area represented in the R\&D team) to 0.68 (when there is an equal number of R\&D members across all three skills areas). We structured education into four categories: 1) PhD, 2) Bachelor, 3) Secondary education, and 4) other studies (i.e., vocational training, etc.). In this case, Blau's index varies from 0 (when all $R \& D$ team members fall within the same educational level) to 0.75 (when there are equal numbers of R\&D team members across all educational levels).

\subsubsection{Control variables}

Firm size has been related to innovation capabilities and the novelty of innovations Ettlie

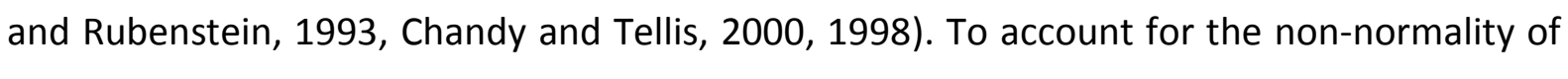
the size measure, a logarithm transformation was used Damanpour, 1992. In addition, we account for non-linear effects of firm size by computing firm size squared Acs and Audretsch, 1991, 1990 .

$R \& D$ team size: the literature in work groups notes that team size is a key variable influencing group dynamics and performance Pelled et al., 1999, Sethi et al., 2001. Large teams have more potential for heterogeneity and this can affect the type of innovation developed by the company López Cabrales et al., 2008. R\&D team size is measured by (the natural logarithm of) the number of full-time employees in the R\&D department. We account for non-linear effects of R\&D team size by computing the squared term. As team size grows, the complexity of the communication structure between members increases 
dramatically Zenger and Lawrence, 1989 leading to greater coordination costs Hoegl, 2005.

Innovation Intensity is defined as the innovation expenditure share of sales de Faria et al., 2010. Innovation expenditure includes internal and external R\&D, acquisition of machinery and acquisition of knowledge for innovation, training for innovation and preparation of the market for the introduction of innovations. Further, we account for a non-linear relationship between innovation intensity and innovative performance by computing the squared term. The impact of innovation intensity on innovative performance decreases when firms proportionally allocate more resources to innovation due to the difficulties to integrate and apply excessive knowledge as greater information and control systems are required (Dyer and Singh, 1998.

Technology Intensity: firms' innovation behaviour is related to their industry affiliation Audretsch, 1997, Malerba et al., 1997; hence we controlled for industry effects following the OECD classification of industries in terms of technology intensity and knowledge intensity $O E C D, 2005$. We created four industry dummies to identify manufacturing firms belonging to high-tech, medium-high, medium-low and low-tech industry; and two dummy variables for service industries: knowledge-intensive business and low knowledge-intensive business services. We used the high-tech industry as the baseline for manufacturing models and the knowledge-intensive services for service models.

Year effects: we used firm-level innovation performance data from 2005 to 2012; hence eight year dummies variables were included to control unobserved factors that change over time but remain relatively constant across industries.

\subsection{Method and data analysis}

To test that all three diversity criteria show an adequate level of heterogeneity and are comparable in their level of diversity, we normalised our diversity indices on a 0 to 1 metric scale by dividing them by their respective operational maximum (Spickermann et al., 2014). Table 2 indicates that our sample shows comparably adequate diversity across the three dimensions included in the study.

\section{Insert Table 2 here}


Table 3 provides the descriptive statistics of each of the variables. Correlation values among all variables are generally low to moderate, suggesting low collinearity risks. The highest correlation is 0.55, far less than the problematic level (0.75) (Tsui et al., 1995). This is confirmed by the analysis of Variance of Inflation (Vif). The maximum Vif value is 1.58 , well below the rule of thumb cut-off of 10 , which again indicates that there were no serious multicollinearity problems in the models Neter et al., 1996.

As predicted, the correlation matrix shows that incremental innovation is significantly correlated with gender $(r=.05, p<.01)$, skills $(r=.05, p<.01)$, and education diversity $(r=.06$, $p<.01)$. However, radical innovation is significantly correlated with gender $(r=.02, p<.01)$, and education diversity $(r=.01, p<.01)$, but not with skills diversity $(r=.01, n s)$. Faultline research shows that the alignment of diversity characteristics would result in the formation of subgroups Lau and Murnighan, 2005. Hence, the correlations of the various diversity dimensions included in this study might account for certain interactions between the individual measures concerning innovation output estimates.

\section{Insert Table 3 here}

We use Tobit regression models to test the main effects of diversity facets on innovative performance ( $\mathrm{H} 1$ to $\mathrm{H} 3$ ). The dependent variables (radical and incremental innovation performance) are percentage measures and thereby conditioned on values between $0 \%$ and $100 \%$. Since the distribution of radical and incremental innovation is highly skewed to the left, the assumption of a normal distribution of the residuals made in a Tobit analysis is violated (significance of Shapiro-Wilk test of 0.000 for both dependent variables). Thus, we use the logarithmic transformation of the Tobit model Filippucci et al., 1996, Papalia and Di lorio, 2001. In addition, we lagged all explanatory and control variables (except for industry dummies which do not vary across panel waves) by one period, consistent with the survey implementation rhythm, to avoid simultaneity and reverse causality problems (Mairesse and Mohnen, 2010. This reduced our sample to an unbalanced panel of seven years and 35,107 observations.

To test the interaction effects ( $\mathrm{H} 4$ to $\mathrm{H} 6)$, we used hierarchical regression analysis Frazier et al., 2004. To prevent multicollinearity problems between the main effects and the interaction effects, all diversity measures were mean-centered before calculating the 
interaction terms Aiken and West, 1991, and subsequently checked to ensure that all Vif values were below 10 (Neter et al., 1996). The Tobit regression models show an overall adequate level of validity according to various statistics commonly used for interpretation Hair et al., 2010: highly significant model chi-squares; further, the smaller values of the Akaike information criterion (AIC) and the Bayesian information criterion (BIC) in models compared with each previous model suggest that the relative goodness of fit in each model improved significantly on the previous one. The Tobit regression models were estimated using STATA 13.

\section{Results}

\subsection{Main Effects of Diversity on Innovative Performance}

Models 1 and 7 (manufacturing - Table 4) and Models 13 and 19 (service - Table 5) present the effects of the control variables. R\&D team size has a significant and positive effect on the likelihood of introducing both radical and incremental innovation; however the quadratic effect is negative indicating that additional increases in R\&D team size will reduce the probability of additional radical and incremental innovations. Innovation intensity has a significant and positive effect on radical innovation, as expected, since radical innovation embodies new knowledge so greater innovation support is required; however the quadratic effect is negative indicating that additional increases in innovation expenditure will reduce the probability of radical innovation. Firm size also has a significant and positive effect on innovative performance for all models but Model 19; the quadratic effect is negative for incremental innovation suggesting that although larger firms tend to introduce more incremental innovations than smaller firms, the oversize can generate monitoring costs and management problems that decrease the probability of introducing incremental and radical innovations.

Models 2 and 8 (manufacturing - Table 4) and Models 14 and 20 (service - Table 5) tested $\mathrm{H} 1$ (gender), H2 (skills) and H3 (education), that diversity variables are positively associated to incremental and radical innovation performance. A diverse gender composition of R\&D teams is positively associated with radical (manufacturing and service) and incremental (manufacturing) innovation. Hence, H1 is largely accepted. Skills diversity influences radical (manufacturing) and incremental (manufacturing and service) innovation. Thus, $\mathrm{H} 2$ is largely 
accepted. Diversity in education exhibits the same impacts as gender diversity; however, it holds the strongest effect of all diversity measures for radical innovation. Consequently, H3 is largely accepted. These findings corroborate our premise that diversity is a multidimensional construct that impacts innovative performance differently depending on the novelty of innovation and industry context. In manufacturing sectors, both surface and deep-level diversity positively impacts performance outcomes although education and skills attributes that form a team's cognitive resource base have the strongest effect on radical innovation. In contrast, diversity has a more limited impact in the service sector with distinct impacts depending on the novelty of innovation.

\subsection{Moderation Effects}

$\mathrm{H} 4$ predicts that skills diversity positively moderates the education diversity-innovative performance link. Contrary to our hypothesised relationship, the interaction term for skills diversity $\mathrm{x}$ education diversity is significant but negative for all models but Model 10 (radical manufacturing innovation). A simple slope analysis Aiken and West, 1991, Dawson, 2014 shows that, at low levels of R\&D team skills diversity, there is a significantly positive relationship between educational diversity and incremental innovation (manufacturing: 8 $=0.315, p<0.05$; service: $B=0.380, p<0.05)$, while at high levels of skills diversity, the relationship between educational diversity and incremental innovation is not statistically significant (manufacturing: $b=-.046$, n.s.; service: $B=-.144$, n.s.) (Figures $2 a$ and 2b). The differences between the slopes were significant (manufacturing: $\mathrm{t}$ value $=-2.90, p<0.05$; service: $\mathrm{t}$ value $=-2.81 ; p<0.05)$. Regarding radical innovation in the service sector, Figure $2 \mathrm{c}$ shows that the positive effect of R\&D team education diversity on radical innovation increases more slowly as skills diversity increases. This result indicates that skills diversity weakens the positive effect of education diversity. The difference between the slopes was significant ( $\mathrm{t}$ value $=-2.31, p<0.05$ ).

The interaction term for gender $x$ education diversity $(\mathrm{H} 5)$ is also significantly negative for radical manufacturing innovation (Model 9 in Table $4,6=-.352, p<0.1$ ), further the main effect is positive (Model 7 in Table $4, b=.132, p<0.05$ ). In service firms, gender diversity negatively moderates the effect of education diversity on incremental innovation (Model 15 in Table 5, $6=-.808, p<0.05$ ), which remains consistent in the full model (Model 18, $6=-$. 
$681, p<0.05)$. It should be noted that the main effect of gender diversity is not significant (Model 13 in Table $5, b=.149, p>.10$ ). Figure 3 a shows that the positive effect of educational diversity on radical manufacturing innovation increases more slowly when gender diversity increases. The difference between the slopes was significant (t value = $2.27, p<0.05)$. For service firms, at high levels of gender diversity, the relationship between educational diversity and incremental innovation is not significant $(\beta=-.173, n . s$. $)$ whereas at low levels of gender diversity, the relationship is positive and significant $(B=.479, p<$ .005) (Figure 3b). The difference between the slopes was significant (t value $=-3.63, p$ $<0.001)$. Consequently, H5 is not supported.

We found similar results for the interaction term for gender $x$ skills diversity (H6). Figure $4 a$ shows a negative moderating effect for radical manufacturing innovation with a positive relationship between R\&D team skills diversity and radical innovation for low levels of gender diversity $(\beta=0.381, p<.001)$ whereas the relationship is not statistically significant for high levels of gender diversity $(\beta=.0007$, n.s.). The difference between the slopes was significant (t value $=-2.28, p<0.05$ ). For service firms (Figure $4 b$ ), at high levels of gender diversity, the relationship between skills diversity and incremental innovation is not significant $(\beta=.040$, n.s.) whereas at low levels of gender diversity, the relationship is positive and significant $(\beta=.474, p<.001)$. The difference between the slopes was significant ( $\mathrm{t}$ value $=-1.79, \mathrm{p}<0.1$ ). Hence, $\mathrm{H} 6$ is not supported. Taken together, these findings indicate that increasing levels of gender diversity lead to the formation of homogeneous subgroups in $R \& D$ teams, creating as a result social barriers and constituting a principal impediment to group cohesion Blau, 1977). When group cohesion is undermined, group performance suffers.

\subsection{Robustness checks}

Several robustness checks have been carried out to assess the sensitivity of the results to changes in model specifications. We estimated our model using OLS and Poisson regression and the results were consistent. Additionally, we applied an Ordered Probit model similar to Henkel (2006) where the dependent variable can take values between 1 and 5 (' 1 ' indicates that the share lies in the first quartile (0-20\%), ' 2 ' between $21-40 \%$, etc.). This model specification allows for a non-linear dependence of the share of sales from radical and 
incremental innovation on the explanatory variables inside the interval $(0 \%-100 \%]$. The results were highly robust to these changes in specification.

\section{Insert Tables 4 and 5 here}

Insert Figures 2, 3 and 4 here

\section{Discussion and conclusions}

Our aim in this research has been to add to our understanding of the performance effects of R\&D team composition. The multiple and often contradictory group dynamics that emerge in heterogeneous teams present organisations with major challenges Post et al., 2009. Specifically, we hoped to demonstrate the significance of the specific context/task in which different facets of diversity impact R\&D team processes and outcomes Haas, 2010. Further, we provide support to the call for a more holistic view of the overall influence of team heterogeneity on innovativeness Shore et al., 2009.

We find supportive evidence that R\&D team composition influence innovative performance; however, the effect of diversity differs in terms of the dimension considered and the novelty of innovation López Cabrales et al., 2008). Further, our findings show different impacts for manufacturing and service industries, supporting the view that these sectors differ fundamentally in innovation processes and tasks, which, in turn, affect their human resource practices Jackson and Schuler, 1995, Joshi and Roh, 2009. In manufacturing firms, both surface and deep-level diversity positively impacts performance outcomes whereas diversity has a more limited impact in the service sector with distinct impacts depending on the novelty of innovation.

Our results show positive effects of information diversity on innovative performance. Sharing, processing and integration of diverse opinions and approaches to problem solving on the basis of R\&D team members' own area of expertise and background positively impact innovation novelty. Findings suggest that though diversity (i.e., variety of education and skills) (Post et al., 2009) in R\&D teams has the strongest effect on radical innovation, in particular education diversity, whereas gender diversity is more relevant for incremental innovation in manufacturing firms. These results correspond with Jehn et al. (1999, who 
reported a positive relationship between information diversity and team performance in high complex tasks.

Despite recent theorising that faultlines, and specially task-related faultlines might enhance creativity (e.g., Nishii and Goncalo, 2008, Bezrukova and Uparna, 2009, our moderation results suggest that excessive diversity could lead to less than desirable outcomes in R\&D teams. R\&D team members' education is tightly linked to their gender and skills, leading to the formation of subgroups created by aligned characteristics Gibson and Vermeulen, 2003. As subcategories develop within R\&D teams, group cohesion is undermined and group performance suffers Faems and Subramanian, 2013). R\&D team members' open expression of their distinctive perspectives and expertise might generate conflict and distrust among R\&D team, affecting team performance.

\subsection{Contributions and Managerial Implications}

Extending prior diversity research (e.g., Jackson and Joshi, 2004 and consistent with a growing body of evidence from research on group faultline (e.g., Bezrukova et al., 2009, Gibson and Vermeulen, 2003, this papers enhances our understanding of the performance implications of R\&D team diversity by considering multiple diversity facets simultaneously Lau and Murnighan, 1998. The fragmentation effects from increasing diversity underscore the importance of going beyond merely increasing R\&D team diversity to focusing how surface-level and deep-level diversity facets interact and how diversity can be managed to avoid possible conflict and distrust.

Our study provides managers with valuable insights on how diversity can be used as a valuable human capital to foster creativity and innovation. R\&D team configuration is within the control of the firm, as such, firms have the flexibility and discretion to encourage or discourage diversity Auh and Menguc, 2005. Overall, all three diversity facets positively impact firm innovation performance, confirming our hypothesising that diversity is a valuable strategy as it provides greater cognitive diversity. Innovativeness is enhanced when R\&D team members exhibit a heterogeneous profile; however, the influence of each diversity facet varies depending on the novelty of innovation and industry. Hence, careful consideration should be given to the appropriate mix of capabilities rather than the absolute level of capabilities. 
Interaction effects in particular suggest that too much heterogeneity could be detrimental to firm innovation performance. Diversity-oriented HRM practices can capitalise on the benefits from diverse $R \& D$ teams by reducing the potential for misunderstanding and conflict. Training and facilitation in conflict resolution and negotiation would enable R\&D team members to integrate diversity of perspectives and information into the group Ancona and Caldwell, 1992. Training team members to understand the perspective of others helps group formation Williams et al., 2007. Beyond individual interventions, HRM practices should also focus on systems and processes, including organisational rewards for team collective performance, which might help mitigate surface-level differences and encourage greater cooperation Harrison et al., 2002, Swanson and Holton, 2009).

\subsection{Limitations and Future Research}

We acknowledge several limitations in our paper and suggest related opportunities for future research. First, this paper examines the influence of diversity in R\&D teams on innovative performance. Future diversity studies should expand beyond R\&D teams to consider heterogeneity related to various dimensions and levels within the firms, including interactions with top management in innovation processes Harrison et al., 1998. Second, our findings suggest that R\&D teams' education diversity is tightly coupled with gender and skills diversity, with a resulting detrimental impact on team performance. Future research should therefore seek to expand our research by investigating the moderating role of R\&D organisational capabilities (i.e., processes, roles and systems) to leverage diversity as a strategic resources to foster innovation and creativity. Third, future studies should explore the potential curvilinear relationship between R\&D team diversity and performance outcomes to better understand the complexities surrounding team diversity (Horwitz and Horwitz, 2007. Fourth, our data does not capture information on how R\&D teams are structured. Different R\&D structures (i.e., centralised vs autonomous R\&D teams linked to SBUs) might activate or inhibit certain group faultlines resulting in different R\&D team performance. Finally, we use data from Spain, where R\&D team diversity is rather limited, particularly regarding female participation in science and technology Mauleón and Bordons, 2014, Bordons et al., 2009. Hence, our data does not exhibit an equal distribution of firms across all diversity variables. Evidence from other countries on the differential effect of group heterogeneity on innovative performance might help to develop more 
general empirical evidence. Specifically, future studies should consider the influence of country-specific dimensions (i.e., culture, institutions), in innovation performance in crosscountry studies.

\section{References}

ACS, Z. J. \& AUDRETSCH, D. B. 1990. Innovation and Small Firms, ed., Boston: MIT Press.

ACS, Z. J. \& AUDRETSCH, D. B. 1991. R\&D, firm size and innovative activity. In: ACS, Z. J. \& AUDRETSCH, D. B. (eds.) Innovation and Technological Change: an International Comparison. New York: Harvester Wheatsheaf.

AIKEN, L. S. \& WEST, S. G. 1991. Multiple regression: Testing and interpreting interactions, ed., Newbury Park: Sage.

ANCONA, D. \& CALDWELL, D. 1992. Demography and design: predictors of new product team performance. Organization Science, 3, 321-241.

ATUAHENE-GIMA, K. \& EVANGELISTA, F. 2000. Cross-Functional Influence in New Product Development: An Exploratory Study of Marketing and R\&D Perspectives. Management Science, 46, 10, 1269-1284.

AUDRETSCH, D. B. 1997. Technological regimes, industrial demography and the evolution of industrial structures. Industrial and Corporate Change, 6, 49-82.

AUH, S. \& MENGUC, B. 2005. Top management team diversity and innovativeness: The moderating role of interfunctional coordination. Industrial Marketing Management, 34, 3, 249-261.

BAGSHAW, M. 2004. Is diversity divisive? A positive training approach. Industrial and Commercial Training, 36, 4, 153 - 157.

BERNTHAL, P. R. \& INSKO, C. A. 1993. Cohesiveness without groupthink: the interactive effects of social and task cohesion. Group \& Organization Management, 18, 1, 66-87.

BEZRUKOVA, K., JEHN, K. A., ZANNUTTO, E. L. \& THATCHER, S. M. B. 2009. Do Workgroup Faultlines Help or Hurt? A Moderated Model of Faultlines, Team Identification, and Group Performance. Organization Science, 20, 1, 35-50.

BEZRUKOVA, K., THATCHER, S. M. B. \& JEHN, K. 2007. Group heterogeneity and faultlines: Comparing alignment and dispersion theories of group composition. In: BEHFAR, K. J. \& THOMPSON, L. L. (eds.) Conflict in Organizational Groups: New Directions in Theory and Practice. Evanston, IL: The Northwestern University Press. 
BEZRUKOVA, K. \& UPARNA, J. 2009. Group splits and culture shifts: A new map of the creativity terrain. In: NEALE, M. A., MANNIX, B. \& GONCALO, J. (eds.) Research on Managing Groups and Teams. Stamford, CT: JAI Press.

BLAU, P. M. 1977. Inequality and Heterogeneity: A Primitive Theory of Social Structure, ed., New York, NY: The Free Press.

BOLLI, T., RENOLD, U. \& WÖRTER, M. 2015. Vertical Educational Diversity and Innovation Performance. KOF Working Papers No. 395. Zurich.

BORDONS, M., MAULEÓN, E., GOMEZ CARIDAD, I., MORILLO, F., SANCHO, R., FERNANDEZ, M. T., GARCIA, C. \& ARIAS, E. 2009. Indicadores de actividad tecnologica desagregados por sexo. Madrid: Instituto de la Mujer.

BOWERS, C. A., PHARMER, J. A. \& SALAS, E. 2000. When member homogeneity is needed in work teams: A meta-analysis. Small Group Research, 31, 305-327.

BRADLEY, S. W., WIKLUND, J. \& SHEPHERD, D. A. 2010. Swinging a double-edged sword: the effect of slack on entrepreneurial management and growth. Journal of Business Venturing, 26, 5, 537-554.

CARTON, A. M. \& CUMMINGS, J. N. 2012. A Theory of Subgroups in Work Teams. Academy of Management Review, 37, 3, 441-470.

CASTELLACCI, F. 2008. Technological paradigms, regimes and trajectories: Manufacturing and service industries in a new taxonomy of sectoral patterns of innovation. Research Policy, 37, 6-7, 978-994.

CHANDRASEKARAN, A. \& LINDERMAN, K. 2015. Managing Knowledge Creation in High-Tech R\&D Projects: A Multimethod Study. Decision Sciences, 46, 2, 267-300.

CHANDY, R. K. \& TELLIS, G. J. 1998. Organizing for radical product innovation: the overlooked role of willingness to cannibalize. Journal of Marketing Research, 35, 474-487.

CHANDY, R. K. \& TELLIS, G. J. 2000. The incumbent's curse? Incumbency, size and radical product innovation. Journal of Marketing, 64, 1-17.

COHEN, W. M. \& LEVINTHAL, D. A. 1990. Absorptive capacity: a new perspective on learning and innovation. Administrative Science Quarterly, 35, 1, 128-152.

COX, T., LOBEL, S. A. \& MCLEOD, P. L. 1991. Effects of ethnic group cultural differences on cooperative and competitive behavior on a group task. Academy of Management Journal, 4, 827-847. 
DAHLIN, K. B., WEINGART, L. R. \& HINDS, P. J. 2005. Team diversity and information use. Academy of Management Journal, 48, 6, 1107-1123.

DAILY, C. M., DALTON, D. R. \& CANNELLA, A. A. 2003. Corporate Governance: Decades of Dialogue and Data. Academy of Management Review, 28, 3, 371-382.

DAMANPOUR, F. 1992. Organizational Size and Innovation. Organization Studies, 13, 3, 375 402.

DAWSON, J. F. 2014. Moderation in Management Research: What, Why, When, and How. Journal of Business and Psychology, 29, 1, 1-19.

DE FARIA, P., LIMA, F. \& SANTOS, R. 2010. Cooperation in innovation activities: The importance of partners. Research Policy, 39, 8, 1082-1092.

DESSLER, G. 2001. Leading people and organisation in 21st century, ed., London, England: Prentice Hall.

DÍAZ-GARCÍA, C., GONZÁLEZ-MORENO, A. \& SÁEZ-MARTÍNEZ, F. J. 2013. Gender diversity within R\&D teams: Its impact on radicalness of innovation. Innovation: Management, Policy \& Practice, 15, 2, 149-160.

DOWNS, G. W. \& MOHR, L. B. 1976. Conceptual Issues in the Study of Innovation. Administrative Science Quarterly, 21, 4, 700-714.

DUNBAR, K. 1995. How scientists really reason: Scientific reasoning in real-world laboratories. In: STERNBERG, R. J. \& DAVIDSON, J. E. (eds.) The nature of insight. Cambridge, MA: The MIT Press.

DUNBAR, K. 1997. How scientists think: On-line creativity and conceptual change in science. In: WARD, T. B., SMITH, S. M. \& VAID, J. (eds.) Creative thought: An investigation of conceptual structures and processes. Washington: American Psychological Association.

DYER, J. H. \& SINGH, H. 1998. The Relational View: Cooperative Strategy and Sources of Interorganizational Competitive Advantage. Academy of Management Review, 23, 4, 660-679.

EGAN, T. M. 2005. Creativity in the context of team diversity: Team leader perspective. Advances in Developing Human Resources, 7, 207-225.

ELY, R. J. \& THOMAS, D. A. 2001. Cultural diversity at work: The effects of diversity perspectives on work group processes and outcomes. Administrative Science Quarterly, 46, 229-273. 
ETTLIE, J. E. \& RUBENSTEIN, A. H. 1993. Firm size and product innovation. Journal of Product Innovation Management, 4, 89-108.

EVANGELISTA, R. 2000. Sectoral patterns of technological change in services Economics of Innovation and New Technologies, 9, 183-221.

FAEMS, D. \& SUBRAMANIAN, A. M. 2013. R\&D manpower and technological performance: The impact of demographic and task-related diversity. Research Policy, 42, 9, 1624 1633.

FENWICK, G. D. \& NEAL, D. J. 2001. Effect of Gender Composition on Group Performance. Gender, Work \& Organization, 8, 2, 205-225.

FERNÁNDEZ SASTRE, J. 2015. The impact of R\&D teams' gender diversity on innovation outputs. International Journal of Entrepreneurship and Small Business, 24, 1, 142162.

FILIPPUCCI, C., DRUDI, I. \& PAPALIA, R. B. 1996. Testing the relevance of Tobin's approach for modeling consumption. Economic Notes, 25, 2, 225-247.

FRAZIER, P. A., TIX, A. P. \& BARRON, K. E. 2004. Testing Moderator and Mediator Effects in Counseling Psychology Research. Journal of Counseling Psychology, 51, 1115-134.

GALLOUJ, F. \& WEINSTEIN, O. 1997. Innovation in services. Research Policy, 26, 537-556.

GIBBONS, D. \& OLK, P. M. 2003. Individual and structural origins of friendship and social position among professionals. Journal of Personality and Social Psychology, 84, 2, 340-351.

GIBSON, C. \& VERMEULEN, F. 2003. A Healthy Divide: Subgroups as a Stimulus for Team Learning Behavior. Administrative Science Quarterly, 48, 2, 202-239.

GONZALEZ, J. A. \& DENISI, A. S. 2009. Cross-level effects of demography and diversity climate on organizational attachment and firm effectiveness. Journal of Organizational Behavior, 30, 1, 21-40.

GOODSTEIN, J., GAUTAM, K. \& BOEKER, W. 1994. The effects of board size and diversity on strategic change. Strategic Management Journal, 15, 3, 241-250.

HAAS, H. 2010. How can we explain mixed effects of diversity on team performance? A review with emphasis on context Equality, Diversity and Inclusion: An International Journal, 29, 5, 458 - 490.

HAGEDOORN, J. \& CLOODT, M. 2003. Measuring innovative performance: is there an advantage in using multiple indicators? Research Policy, 32, 1365-1379. 
HAIR, J. F., BLACK, W. C., BABIN, B. J. \& ANDERSON, R. E. 2010. Multivariate Data Analysis, 7th Edition ed., Upper Saddle River, NJ: Prentice Hall-International.

HARRISON, D. A. \& KLEIN, K. J. 2007. What's the difference? Diversity constructs as separation, variety or disparity in organisations. Academy of Management Review, 32, 4, 1199-1228.

HARRISON, D. A., PRICE, K. H. \& BELL, M. P. 1998. Beyond relational demography: Time and the effects of surface- and deep-level diversity on work group cohesion. Academy of Management Journal, 41, 96-107.

HARRISON, D. A., PRICE, K. H., GAVIN, J. H. \& FLOREY, A. T. 2002. Time, teams, and task performance: Changing effects of surface- and deep-level diversity on group functioning. Academy of Management Journal, 45, 1029-1045.

HENKEL, J. 2006. Selective revealing in open innovation processes: the case of embedded Linux. Research Policy, 35, 7, 953-969.

HITT, M. A., HOSKISSON, R. E., JOHNSON, R. A. \& MOESEL, D. D. 1996. The market for corporate control and firm innovation. The Academy of Management Journal, 39, 1084-1119.

HOEGL, M. 2005. Smaller teams-better teamwork: How to keep project teams small. Business Horizons, 48, 3, 209-214.

HONG, L. \& PAGE, S. E. 2004. Groups of diverse problem solvers can outperform groups of high-ability problem solvers. Proc. Natl. Acad. Sci. USA, 101, 46, 16385-16389. HORWITZ, S. \& HORWITZ, I. 2007. The effects of team diversity on team outcomes: A metaanalytic review of team demography. Journal of Management, 33, 6, 987-1015.

ISEKE, A., KOCKS, B., SCHNEIDER, M. R. \& SCHULZE-BENTROP, C. 2015. Cross-cutting organizational and demographic divides and the performance of research and development teams: two wrongs can make a right. $R \& D$ Management, 45, 1, 23-40.

JACKSON, S., MAY, K. \& WHITNEY, K. 1995. Understanding the dynamics of diversity in decision making teams. In: GUZZO, R. \& SALAS, E. (eds.) Team Effectiveness and Decision Making in Organizations. San Francisco: Jossey-Bass.

JACKSON, S. E. 1996. The consequences of diversity in multidisciplinary work teams. In: WEST, M. A. (ed.) The psychology of groups at work. Chichester, UK: John Wiley \& Sons. 
JACKSON, S. E. \& JOSHI, A. 2004. Diversity in social context: A multi-attribute, multi-level analysis of team diversity and performance. Journal of Organizational Behavior, 25, 675-702.

JACKSON, S. E. \& SCHULER, R. S. 1995. Understanding human resource management in the context of organizations and their environments. Annual Review of Psychology, 46, 237-264.

JANIS, I. L. 1972. Victims of Groupthink, ed., New York: Houghton Mifflin.

JEHN, K. A., BEZRUKOVA, K. \& THATCHER, S. 2008. Conflict, diversity, and faultlines in workgroups. In: DE DREU, C. K. W. \& GELFAND, M. (eds.) The Psychology of Conflict and Conflict Management in Organizations. New York, NY: Erlbaum Psych Press.

JEHN, K. A. \& BEZRUKOVA., K. 2010. The faultline activation process and the effects of activated faultlines on coalition formation, conflict, and group outcomes. Organizational Behavior and Human Decision Process, 112, 24-42.

JEHN, K. A., CHADWICK, C. \& THATCHER, S. M. B. 1997. To agree or not to agree: The effects of value congruence, individual demography dissimilarity, and conflict on workgroup outcome. International Journal of Conflict Management, 8, 287-305.

JEHN, K. A., NORTHCRAFT, G. B. \& NEALE, M. A. 1999. Why differences make a difference: A field study of diversity, conflict, and performance in workgroups. Administrative Science Quarterly, 44, 741-763.

JOSHI, A. \& JACKSON, S. 2003. Managing workforce diversity to enhance cooperation in organizations. In: WEST, M. A., TJOSVOLD, D. \& SMITH, K. G. (eds.) International Handbook of Organizational Teamwork and Cooperative Working. Hoboken, NJ: John Wiley \& Sons.

JOSHI, A. \& ROH, H. 2009. The Role Of Context In Work Team Diversity Research: A MetaAnalytic Review. Academy of Management Journal, 52, 3, 599-627.

KATZ, R. \& TUSHMAN, M. 1979. Communication pattners, project performance, and task characteristics: An empirical evaluation and integration in an R\&D setting. Organizational Behaviour and Human Performance, 23, 139-162.

LANGERAK, F., HULTINK, E. J. \& GRIFFIN, A. 2008. Exploring mediating and moderating influences on the links among cycle time, proficiency in entry timing, and new product profitability. Journal of Product Innovation Management, 25, 370-385. 
LAU, D. \& MURNIGHAN, J. K. 1998. Demographic diversity and faultlines: The compositional dynamics of organizational groups. Academy of Management Review, 23, 325-340.

LAU, D. C. \& MURNIGHAN, J. K. 2005. Interactions within groups and subgroups: the effects of demographic faultlines. Academy of Management Journal, 48, 4, 645-659.

LAURSEN, K. \& SALTER, A. 2006. Open for innovation: the roles of openness in explaining innovation performance among UK manufacturing firms. Strategic Management Journal, 27, 2, 131-150.

LIN, J.-Y. 2014. Effects on diversity of R\&D sources and human capital on industrial performance. Technological Forecasting and Social Change, 85, June, 168-184.

LÓPEZ CABRALES, Á., CABELLO MEDINA, C., CARMONA LAVADO, A. \& VALLE CABRERA, R. 2008. Managing functional diversity, risk taking and incentives for teams to achieve radical innovations. $R \& D$ Management, 38, 1, 35-50.

LUNDVALL, B. A. 1988. Innovation as an interactive process: From user-producer interaction to the national system of innovation. In: DOSI, G., FREEMAN, C., NELSON, R. R., SILVERBERG, G. \& SOETE, L. (eds.) Technical Change and Economic Theory. London: Pinter Publishers.

MAIRESSE, J. \& MOHNEN, P. 2010. Using innovations surveys for econometric analysis. In: HALL, B. H. \& ROSENBERG, N. (eds.) Handbook of the Economics of Innovation. Amsterdam: Elsevier B.V.

MALERBA, F., ORSENIGO, L. \& PERETTO, P. 1997. Persistence of innovative activities, sectoral patterns of innovation and international technological specialisation. International Journal of Industrial Organisation, 15, 801-826.

MAULEÓN, E. \& BORDONS, M. 2014. Indicadores de actividad tecnológica por género en España a través del estudio de patentes europeas. Revista Española de Documentación Científica, 37, 2.

MEHRA, A., KILDUFF, M. \& BRASS, D. J. 1998. At the Margins: A Distinctiveness Approach to the Social Identity and Social Networks of Underrepresented Groups. The Academy of Management Journal, 41, 4, 441-452.

MILLIKEN, F. J. \& MARTINS, L. L. 1996. Searching for common threads: Understanding the multiple effects of diversity in organizational groups. Academic of Management Review, 21, 2, 402-433. 
MINTZBERG, H. 1983. Power In And Around Organizations, ed., Englewood Cliffs, N.J: Prentice-Hall, Inc. .

MOLLEMAN, E. 2005. Diversity in demographic characteristics, abilities and personality traits: Do faultlines affect team functioning? Group Decision and Negotiation, 14, 173-193.

NEMETH, C. J. \& GONCALO, J. A. 2005. Influence and persuasion in small groups. In: BROCK, T. C. \& GREEN, M. C. (eds.) Persuasion: Psychological insights and perspectives. London: Sage Publications.

NETER, J., KUTNER, M. H., NACHTSHEIM, C. J. \& WASSERMAN, W. 1996. Applied linear statistical models, 4th ed., Chicago: Irwin/McGraw-Hill.

NIELSEN, S. \& HUSE, M. 2010a. The Contribution of Women on Boards of Directors: Going beyond the Surface. Corporate Governance: An International Review, 18, 2, 136-148.

NIELSEN, S. \& HUSE, M. 2010b. Women directors' contribution to board decision-making and strategic involvement: The role of equality perception. European Management Review, 7, 1, 16-29.

NISHII, L. H. \& GONCALO, J. A. 2008. Demographic fault lines and creativity in diverse groups. In: PHILLIPS, K. W., MANNIX, E. A. \& NEALE, M. A. (eds.) Research on Managing Groups and Teams. Greenwich, CT: JAI Press.

NONAKA, I. \& TAKEUCHI, H. 1995. The knowledge-creating company, ed., New York, Oxford: Oxford University Press.

O'REILLY, C. A., WILLIAMS, K. Y. \& BARSADE, S. 1998. Group demography and innovation: Does diversity help? In: GRUENFIELD, D. \& NEALE, M. A. (eds.) Research on managing in groups and teams. Stamford, CT: JAI Press.

OECD 2002. Frascati Manual. Proposed Standard Practice for Surveys on Researchand Experimental Development, ed., Paris: OECD Publications.

OECD 2005. Oslo Manual. Guidelines for Collecting and Interpreting Innovation. 3rd Edition, 3rd ed., Paris: OECD Publications.

ØSTERGAARD, C. R., TIMMERMANS, B. \& KRISTINSSON, K. 2011. Does a different view create something new? The effect of employee diversity on innovation. Research Policy, 40, 3, 500-509.

PAGE, S. E. 2007. The Difference: How the Power of Diversity Creates Better Groups, Firms, Schools and Societies, ed., Princeton, NJ: Princeton University Press. 
PAPALIA, R. \& DI IORIO, F. 2001. Alternative Error Term Specifications in the Log-Tobit Model1. In: BORRA, S., ROCCI, R., VICHI, M. \& SCHADER, M. (eds.) Advances in Classification and Data Analysis. Springer Berlin Heidelberg.

PELLED, L., EISENHARDT, K. \& XIN, K. 1999. Exploring the black box: An analysis of work group diversity, conflict, and performance. Administrative Science Quarterly, 44, 128.

PODSAKOFF, P., MACKENZIE, S., LEE, J. \& PODSAKOFF, N. 2003. Common method biases in behavioral research: a critical review of the literature and recommended remedies. Journal of Applied Psychology, 88, 5, 879-903.

POST, C., DE LIA, E., DITOMASO, N., TIRPAK, T. M. \& BORWANKAR, R. 2009. Capitalizing on Thought Diversity for Innovation. Research-Technology Management, 52, 6, 14-25.

RICO, R., SANCHEZ-MANZANARES, M., ANTINO, M. \& LAU, D. C. 2012. Bridging team faultlines by combining task role assignment and goal structure strategies. Journal of Applied Psychology, 97, 407-420.

ROBERGE, M.-É. \& VAN DICK, R. 2010. Recognizing the benefits of diversity: When and how does diversity increase group performance? Human Resource Management Review, 20, 4, 295-308.

SETHI, R., SMITH, D. C. \& PARK, C. W. 2001. Crossfunctional product development teams, creativity, and the innovativeness of new consumer products. Journal of Marketing Research, XXXVIII, 73-85.

SHORE, L. M., CHUNG-HERRERA, B. G., DEAN, M. A., EHRHART, K. H., JUNG, D. I., RANDEL, A. E. \& SINGH, G. 2009. Diversity in organizations: Where are we now and where are we going? Human Resource Management Review, 19, 2, 117-133.

SIMONS, T., PELLED, L. H. \& SMITH, K. A. 1999. Making Use of Difference: Diversity, Debate, and Decision Comprehensiveness in Top Management Teams. Academy of Management Journal, 42, 6, 662-673.

SINGH, V., TERJESEN, S. \& VINNICOMBE, S. 2008. Newly appointed directors in the boardroom:: How do women and men differ? European Management Journal, 26, 1, 48-58.

SIRILLI, G. \& EVANGELISTA, R. 1998. Technological innovation in services and manufacturing: results from Italian surveys. Research Policy, 27, 9, 881-899. 
SOFKA, W. \& GRIMPE, C. 2010. Specialised search and innovation performance: evidence across Europe. R\&D Management, 40, 3, 310-323.

SOLLNER, R. 2010. Human Capital Diversity and Product Innovation: A Micro-Level Analysis. Jena Economic Research Papers- 027.

SPICKERMANN, A., ZIMMERMANN, M. \& VON DER GRACHT, H. A. 2014. Surface- and deeplevel diversity in panel selection - Exploring diversity effects on response behaviour in foresight. Technological Forecasting and Social Change, 85, 0, 105-120.

SUTTON, R. I. 2007. Weird Ideas That Work: How to Build a Creative Company, ed., New York: Free Press.

SWANSON, R. \& HOLTON, E. 2009. Foundations of Human Resource Development, 2nd ed., San Francisco, CA: Berrett-Koehler.

TAJFEL, H. 1978. Differentiation Between Social Groups: Studies in the Social Psychology of Intergroup Relations, ed., London: Academic Press.

TALKE, K., SALOMO, S. \& ROST, K. 2010. How top management team diversity affects innovativeness and performance via the strategic choice to focus on innovation fields. Research Policy, 39, 7, 907-918.

THATCHER, S. M. B. \& PATEL, P. C. 2012. Group faultlines: A review, integration, and guide to future research. Journal of Management, 38, 969-1009.

THATCHER, S. M. B. \& PATEL, P. C. 2011. Demographic faultlines: A meta-analysis and synthesis of the literature. Journal of Applied Psychology, 96, 1119-1139.

TSUI, A. S., ASHFORD, S. J., CLAIR, L. S. \& XIN, K. R. 1995. Dealing with Discrepant Expectations: Response Strategies and Managerial Effectiveness. Academy of Management Journal, 38, 6, 1515-1543.

TURNER, J. C., HOGG, M. A., OAKES, P. J., REICHER, S. D. \& WETHERELL, M. S. 1987. Rediscovering the Social Group: A self-categorization Theory, ed., New York: Blackwell.

VAN DER VEGT, G. \& JANSSEN, O. 2003. Joint impact of interdependence and group diversity on innovation. Journal of Management, 29, 5, 729-751.

VAN KNIPPENBERG, D., DE DREU, C. \& HOMAN, A. C. 2004. Work group diversity and group performance: An integrative model and research agenda. Journal of Applied Psychology, 89, 1008-1022. 
VAN KNIPPENBERG, D. \& SCHIPPERS, M. C. 2007. Work group diversity. Annual Review of Psychology, 58, 515-541.

WILLIAMS, H., PARKER, S. \& TURNER, N. 2007. Perceived dissimilarity and perspective taking within work teams. Group and Organization Management, 32, 5, 569-597.

WILLIAMS, K. \& O’REILLY, C. 1998. Demography and diversity in organizations: a review of 40 years of research. In: STAW, B. \& CUMMINGS, L. (eds.) Research in Organizational Behavior. Greenwich: JAI Press.

WITTENBAUM, G. M. \& STASSER, G. 1996. Management of Information in Small Groups. In: NYE, J. L. \& BROWER, A. M. (eds.) What's Social About Social Cognition? Research on Socially Shared Cognition in Small Groups. Thousand Oaks, CA: Sage.

WOOD, W. 1987. Meta-analytic review of sex differences in group performance. Psychological Bulletin, 102, 53-71.

WOODMAN, R. W., SAWYER, J. E. \& GRIFFIN, R. W. 1993. Toward a Theory of Organizational Creativity. The Academy of Management Review, 18, 2, 293-321.

YANG, Y., NARAYANAN, V. K. \& ZAHRA, S. 2009. Developing the selection and valuation capabilities through learning: The case of corporate venture capital. Journal of Business Venturing, 24, 3, 261-273.

ZENGER, T. R. \& LAWRENCE, B. S. 1989. The differential effects of age and tenure distributions on technical communication. Academy of Management Journal, 32, 2, 353-376. 
Table 1. Samples descriptive statistics

\begin{tabular}{llcc}
\hline Variables & Characteristics & $\begin{array}{c}\text { Manufacturing firms } \\
\text { \% }\end{array}$ & $\begin{array}{c}\text { Service firms } \\
\%\end{array}$ \\
\hline Gender & Male & 74.2 & 69.8 \\
Education & Female & 25.8 & 30.2 \\
& PhD & 5.1 & 8.1 \\
& Bachelor & 42.7 & 56.7 \\
Skills & Secondary education & 22.8 & 19.8 \\
& Other studies & 29.4 & 15.4 \\
& Researchers & 43.1 & 51.5 \\
Number of employees (size) & Technicians & 42.5 & 41.6 \\
& Supporting staff & 14.4 & 6.9 \\
& Less than 50 & 44.2 & 61.9 \\
& Between 50-99 & 20 & 11.3 \\
R\&D team size & Between 100-449 & 28.7 & 16.9 \\
& 500 or more & 7.1 & 9.9 \\
& Less than 5 members & 47.7 & 43.8 \\
& Between 5-19 members & 39.6 & 36.9 \\
& Between 20-39 members & 7.4 & 9.5 \\
\hline
\end{tabular}

Table 2. Standardised diversity indices (Blau's index of heterogeneity)

\begin{tabular}{lccc}
\hline & Full sample & Manufacturing firms & Service firms \\
\hline Gender & 0.46 & 0.42 & 0.52 \\
\hline Skills & 0.51 & 0.52 & 0.43 \\
\hline Education & 0.49 & 0.55 & 0.44 \\
\hline
\end{tabular}

Table 3. Means, Standard Deviations and Correlation Coefficients

\begin{tabular}{|c|c|c|c|c|c|c|c|c|c|c|}
\hline Variable & Mean & S.D. & 1 & 2 & 3 & 4 & 5 & 6 & 7 & 8 \\
\hline 1. Radica Innovation & 13.99 & 25.78 & 1 & & & & & & & \\
\hline 2. Increm Innovation & 40.44 & 42.96 & $-0.16 * *$ & 1 & & & & & & \\
\hline 3. Gender & 0.23 & 0.20 & $0.02 * *$ & $0.05^{* *}$ & 1 & & & & & \\
\hline 4. Education & 0.37 & 0.24 & $0.02^{* *}$ & $0.06 * *$ & $0.25^{* *}$ & 1 & & & & \\
\hline 5. Skills & 0.34 & 0.23 & 0.01 & $0.05^{* *}$ & $0.21 * *$ & $0.55^{* *}$ & 1 & & & \\
\hline 6. Firm Size (Ln) & 4.10 & 1.56 & $-0.07 * *$ & $0.08 * *$ & $0.21 * *$ & $0.22 * *$ & $0.15^{* *}$ & 1 & & \\
\hline 7. R\&D team Size (Ln) & 1.29 & 1.37 & $0.11^{* *}$ & $0.08 * *$ & $0.37 * *$ & $0.42 * *$ & $0.35^{* *}$ & $0.49 * *$ & 1 & \\
\hline 8. Inn intensity & 0.18 & 0.52 & $0.12^{* *}$ & $-0.04 * *$ & $0.09 * *$ & $0.02 * *$ & -0.01 & $-0.24 * *$ & $0.16^{* *}$ & 1 \\
\hline Vif & & & 1.42 & 1.43 & 1.40 & 1.29 & 1.30 & 1.27 & 1.22 & 1.35 \\
\hline
\end{tabular}

S.D, standard deviation; Vif, Variance Inflation Factor 
Table 4 - Results of Tobit regression analysis: effect of diversity on firm innovation performance (manufacturing firms)

\begin{tabular}{|c|c|c|c|c|c|c|c|c|c|c|c|c|}
\hline & \multicolumn{6}{|c|}{ Incremental innovation } & \multicolumn{6}{|c|}{ Radical innovation } \\
\hline & Model 1 & Model 2 & Model 3 & Model 4 & Model 5 & Model 6 & Model 7 & Model 8 & Model 9 & Model 10 & Model 11 & Model 12 \\
\hline & $B(S . E)$ & $B(S . E)$ & $B(S . E)$ & $B(S . E)$ & $B(S . E)$ & $B(S . E)$ & $B(S . E)$ & $B(S . E)$ & $B(S . E)$ & $B(S . E)$ & $B(S . E)$ & $B(S . E)$ \\
\hline \multicolumn{13}{|l|}{ R\&D Team Diversity } \\
\hline H1: Gender & & $\begin{array}{c}0.335^{* * *} \\
(0.063)\end{array}$ & $\begin{array}{c}0.335^{* * *} \\
(0.063)\end{array}$ & $\begin{array}{c}0.323 * * * \\
(0.063)\end{array}$ & $\begin{array}{c}0.337 * * * \\
(0.063)\end{array}$ & $\begin{array}{c}0.323 * * * \\
(0.063)\end{array}$ & & $\begin{array}{c}0.132 * * \\
(0.064)\end{array}$ & $\begin{array}{c}0.135^{* *} \\
(0.064)\end{array}$ & $\begin{array}{l}0.124^{*} \\
(0.064)\end{array}$ & $\begin{array}{c}0.143^{* *} \\
(0.064)\end{array}$ & $\begin{array}{c}0.137^{* *} \\
(0.064)\end{array}$ \\
\hline H2: Skills & & $\begin{array}{c}0.291 * * \\
(0.087)\end{array}$ & $\begin{array}{c}0.291 * * \\
(0.087)\end{array}$ & $\begin{array}{c}0.251 * * * \\
(0.088)\end{array}$ & $\begin{array}{c}0.287 * * * \\
(0.087)\end{array}$ & $\begin{array}{c}0.255^{* *} \\
(0.089)\end{array}$ & & $\begin{array}{c}0.213^{* *} \\
(0.088)\end{array}$ & $\begin{array}{c}0.194 * * \\
(0.088)\end{array}$ & $\begin{array}{c}0.186^{* *} \\
(0.089)\end{array}$ & $\begin{array}{c}0.194^{* *} \\
(0.089)\end{array}$ & $\begin{array}{c}0.178^{* *} \\
(0.089)\end{array}$ \\
\hline H3: Education & & $\begin{array}{l}0.183^{*} \\
(0.094)\end{array}$ & $\begin{array}{l}0.184^{*} \\
(0.095)\end{array}$ & $\begin{array}{l}0.134^{*} \\
(0.097)\end{array}$ & $\begin{array}{l}0.178^{*} \\
(0.096)\end{array}$ & $\begin{array}{c}0.136 \\
(0.097)\end{array}$ & & $\begin{array}{c}0.561 * * * \\
(0.096)\end{array}$ & $\begin{array}{c}0.544^{* * *} \\
(0.096)\end{array}$ & $\begin{array}{c}0.525^{* * *} \\
(0.098)\end{array}$ & $\begin{array}{c}0.531^{* * *} \\
(0.097)\end{array}$ & $\begin{array}{c}0.513^{* * *} \\
(0.098)\end{array}$ \\
\hline \multicolumn{13}{|l|}{ Moderating effects } \\
\hline H4: Skills x Education & & & & $\begin{array}{c}-0.543^{* *} \\
(0.235)\end{array}$ & & $\begin{array}{c}-0.583^{* *} \\
(0.249)\end{array}$ & & & & $\begin{array}{l}-0.389 \\
(0.238)\end{array}$ & & $\begin{array}{l}-0.211 \\
(0.253)\end{array}$ \\
\hline H5: Gender x Education & & & $\begin{array}{c}0.012 \\
(0.192)\end{array}$ & & & $\begin{array}{c}0.154 \\
(0.228)\end{array}$ & & & $\begin{array}{c}-0.352^{*} \\
(0.195)\end{array}$ & & & $\begin{array}{l}-0.105 \\
(0.232)\end{array}$ \\
\hline H6: Gender x Skills & & & & & $\begin{array}{l}-0.089 \\
(0.182)\end{array}$ & $\begin{array}{l}-0.028 \\
(0.220)\end{array}$ & & & & & $\begin{array}{c}-0.464^{* *} \\
(0.185)\end{array}$ & $\begin{array}{l}-0.361 \\
(0.224)\end{array}$ \\
\hline \multicolumn{13}{|l|}{ Control variables } \\
\hline Firm Size & $\begin{array}{c}0.322^{* * *} \\
(0.031)\end{array}$ & $\begin{array}{c}0.252^{* * *} \\
(0.032)\end{array}$ & $\begin{array}{c}0.252^{* * *} \\
(0.032)\end{array}$ & $\begin{array}{c}0.248^{* *} \\
(0.032)\end{array}$ & $\begin{array}{c}0.251^{* * *} \\
(0.032)\end{array}$ & $\begin{array}{c}0.249 * * \\
(0.032)\end{array}$ & $\begin{array}{l}0.062^{*} \\
(0.031)\end{array}$ & $\begin{array}{c}-0.019 \\
(0.033)\end{array}$ & $\begin{array}{l}-0.023 \\
(0.033)\end{array}$ & $\begin{array}{l}-0.022 \\
(0.033)\end{array}$ & $\begin{array}{l}-0.023 \\
(0.033)\end{array}$ & $\begin{array}{l}-0.025 \\
(0.033)\end{array}$ \\
\hline Firm SizeSq & $\begin{array}{c}-0.164 * * * \\
(0.019)\end{array}$ & $\begin{array}{c}-0.141 * * * \\
(0.019)\end{array}$ & $\begin{array}{c}-0.141 * * * \\
(0.019)\end{array}$ & $\begin{array}{c}-0.140 * * * \\
(0.019)\end{array}$ & $\begin{array}{c}-0.141^{* * *} \\
(0.019)\end{array}$ & $\begin{array}{c}-0.141^{* * *} \\
(0.019)\end{array}$ & $\begin{array}{c}0.014 \\
(0.018)\end{array}$ & $\begin{array}{c}0.041^{* *} \\
(0.019)\end{array}$ & $\begin{array}{c}0.043^{* *} \\
(0.019)\end{array}$ & $\begin{array}{c}0.042^{* *} \\
(0.019)\end{array}$ & $\begin{array}{c}0.043 * * \\
(0.019)\end{array}$ & $\begin{array}{c}0.043^{* *} \\
(0.019)\end{array}$ \\
\hline R\&D team Size & $\begin{array}{c}0.178 * * * \\
(0.041)\end{array}$ & $\begin{array}{c}0.129 * * \\
(0.041)\end{array}$ & $\begin{array}{c}0.129 * * \\
(0.041)\end{array}$ & $\begin{array}{c}0.135^{* *} \\
(0.041\end{array}$ & $\begin{array}{c}0.163 * * * \\
(0.051)\end{array}$ & $\begin{array}{c}0.168^{* *} \\
(0.052)\end{array}$ & $\begin{array}{c}0.346^{* * *} \\
(0.040)\end{array}$ & $\begin{array}{c}0.296 * * * \\
(0.040)\end{array}$ & $\begin{array}{c}0.299 * * * \\
(0.040)\end{array}$ & $\begin{array}{c}0.300 * * * \\
(0.040)\end{array}$ & $\begin{array}{c}0.378^{* * *} \\
(0.051)\end{array}$ & $\begin{array}{c}0.381^{* * *} \\
(0.051)\end{array}$ \\
\hline R\&D team SizeSq & $\begin{array}{c}-0.007^{* *} \\
(0.002)\end{array}$ & $\begin{array}{c}-0.005^{* *} \\
(0.002)\end{array}$ & $\begin{array}{c}-0.005^{* *} \\
(0.002)\end{array}$ & $\begin{array}{c}-0.006^{* *} \\
(0.002)\end{array}$ & $\begin{array}{c}-0.009 * * \\
(0.004)\end{array}$ & $\begin{array}{c}-0.009 * * \\
(0.003)\end{array}$ & $\begin{array}{c}-0.012 * * * \\
(0.002)\end{array}$ & $\begin{array}{c}-0.010 * * * \\
(0.002)\end{array}$ & $\begin{array}{c}-0.010 * * * \\
(0.002)\end{array}$ & $\begin{array}{c}-0.010 * * * \\
(0.002)\end{array}$ & $\begin{array}{c}-0.017 * * * \\
(0.003)\end{array}$ & $\begin{array}{c}-0.017^{* * *} \\
(0.003)\end{array}$ \\
\hline Innovation intensity & $\begin{array}{c}0.213 \\
(0.205)\end{array}$ & $\begin{array}{c}0.004 \\
(0.205)\end{array}$ & $\begin{array}{c}0.004 \\
(0.205)\end{array}$ & $\begin{array}{c}-0.001 \\
(0.205)\end{array}$ & $\begin{array}{c}0.002 \\
(0.205)\end{array}$ & $\begin{array}{c}0.002 \\
(0.205)\end{array}$ & $\begin{array}{c}0.428^{* * *} \\
(0.040)\end{array}$ & $\begin{array}{c}0.384^{* * *} \\
(0.001)\end{array}$ & $\begin{array}{c}1.821^{* * *} \\
(0.196)\end{array}$ & $\begin{array}{c}1.827 * * * \\
(0.195)\end{array}$ & $\begin{array}{c}1.819^{* * *} \\
(0.196)\end{array}$ & $\begin{array}{c}1.817^{* * *} \\
(0.196)\end{array}$ \\
\hline Innovation intensitySq & $\begin{array}{c}-0.073^{*} \\
(0.042)\end{array}$ & $\begin{array}{c}-0.401 \\
(0.042)\end{array}$ & $\begin{array}{l}-0.040 \\
(0.042)\end{array}$ & $\begin{array}{c}-0.039 \\
(0.042)\end{array}$ & $\begin{array}{l}-0.039 \\
(0.042)\end{array}$ & $\begin{array}{l}-0.039 \\
(0.042)\end{array}$ & $\begin{array}{c}-0.014 * * * \\
(0.001)\end{array}$ & $\begin{array}{c}-0.012^{* * *} \\
(0.001)\end{array}$ & $\begin{array}{c}-0.267^{* * *} \\
(0.038)\end{array}$ & $\begin{array}{c}-0.268^{* * *} \\
(0.038)\end{array}$ & $\begin{array}{c}-0.273^{* * *} \\
(0.038)\end{array}$ & $\begin{array}{c}-0.267 * * * \\
(0.038)\end{array}$ \\
\hline Intercept & $\begin{array}{c}0.845^{* * *} \\
(0.086)\end{array}$ & $\begin{array}{c}0.448 * * * \\
(0.100)\end{array}$ & $\begin{array}{c}0.845^{* * *} \\
(0.088)\end{array}$ & $\begin{array}{c}0.880^{* * *} \\
(0.089)\end{array}$ & $\begin{array}{c}0.872 * * * \\
(0.087)\end{array}$ & $\begin{array}{c}0.904 * * * \\
(0.089)\end{array}$ & $\begin{array}{l}-0.100 \\
(0.087)\end{array}$ & $\begin{array}{c}-0.580^{* * *} \\
(0.102)\end{array}$ & $\begin{array}{c}-0.190^{* *} \\
(0.089)\end{array}$ & $\begin{array}{c}-0.176^{* *} \\
(0.090)\end{array}$ & $\begin{array}{l}-0.132 \\
(0.088)\end{array}$ & $\begin{array}{l}-0.118 \\
(0.089)\end{array}$ \\
\hline Log-likelihood & -38222.10 & -38184.69 & -38184.68 & -38182.026 & -38184.57 & -38181.77 & -33973.29 & -33928.08 & -33926.46 & -33926.75 & -33924.95 & -33924.45 \\
\hline$x^{2}$ & $4532.92 * * *$ & $4607.74^{* * *}$ & $4607.74^{* * *}$ & $4613.07^{* * *}$ & $4607.98 * * *$ & $4613.58^{* * *}$ & $488.72 * * *$ & $579.15^{* * *}$ & $582.39 * * *$ & $581.81 * * *$ & $585.40 * * *$ & $586.41 * * *$ \\
\hline AIC & 76478.2 & 76409.38 & 76411.38 & 76406.05 & 76411.14 & 76409.54 & 67980.6 & 67896.16 & 67894.92 & 67895.51 & 67891.91 & 67894.9 \\
\hline $\mathrm{BIC}$ & 76614.51 & 76569.74 & 76579.75 & 76574.43 & 76579.52 & 76593.95 & 68116.9 & 68056.52 & 68063.3 & 68063.88 & 68060.29 & 68079.32 \\
\hline
\end{tabular}

Note: S.E., standard error; Year and sector dummy variables were included in the analysis but results are omitted here. 
Table 5 - Results of Tobit regression analysis: effect of diversity on firm innovative performance (service firms)

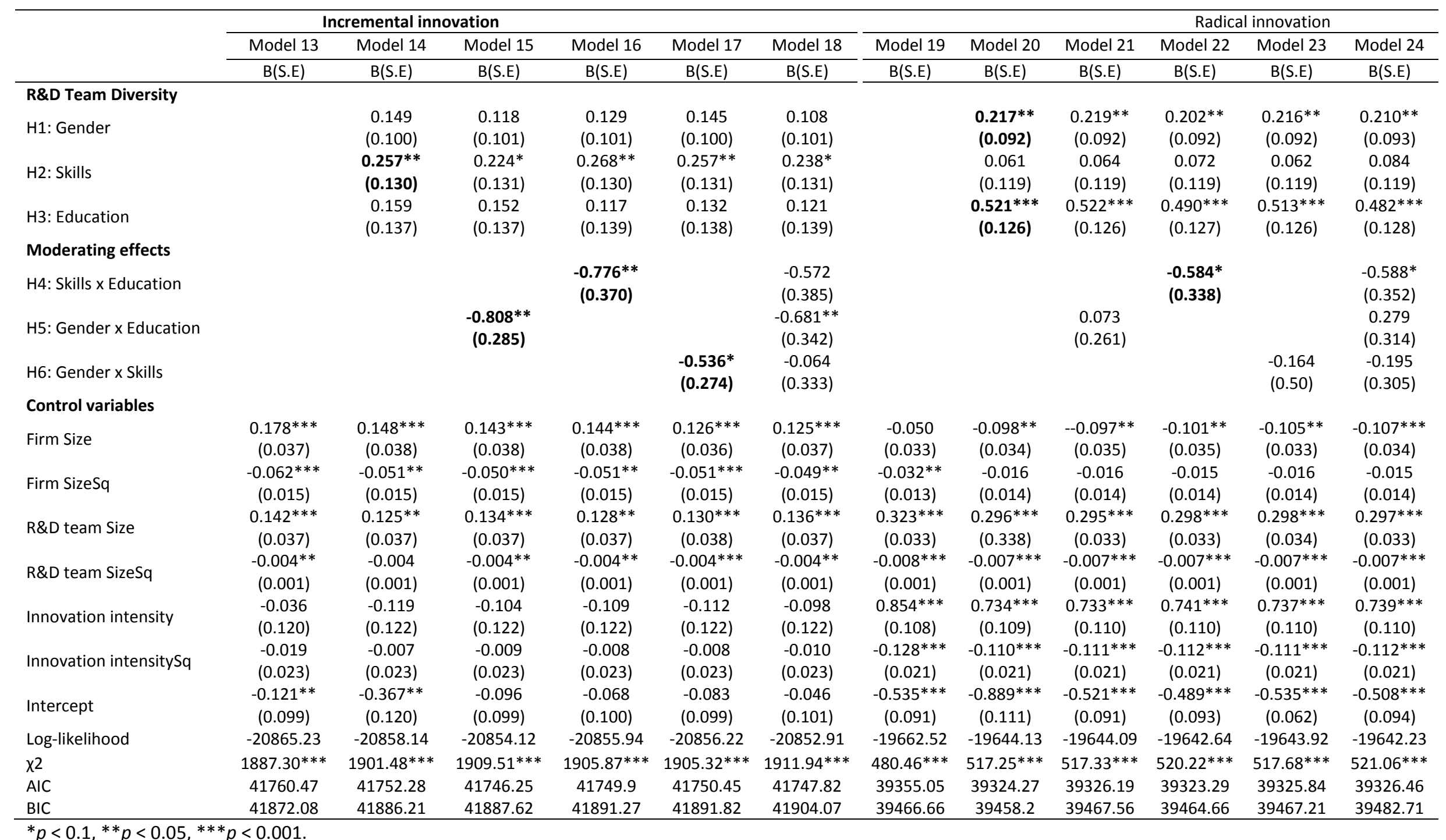

Note: S.E., standard error; Year and sector dummy variables were included in the analysis but results are omitted here. 
Figure 1. Research Framework

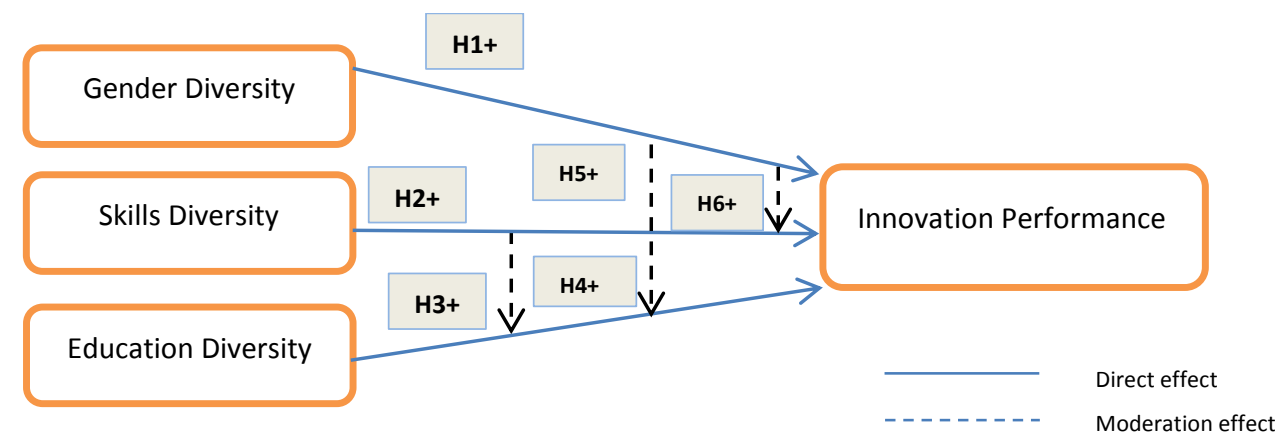

Figure 2. Moderating role of skills diversity on the education diversity-innovation performance relationship
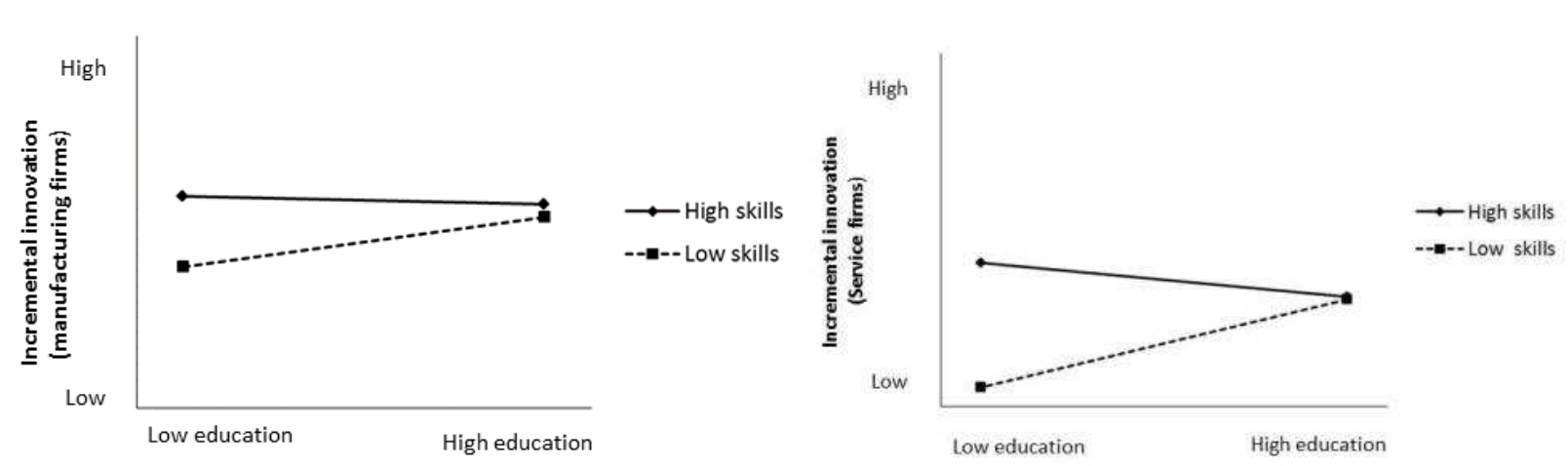

a) Incremental manufacturing innovation

b) Incremental service innovation

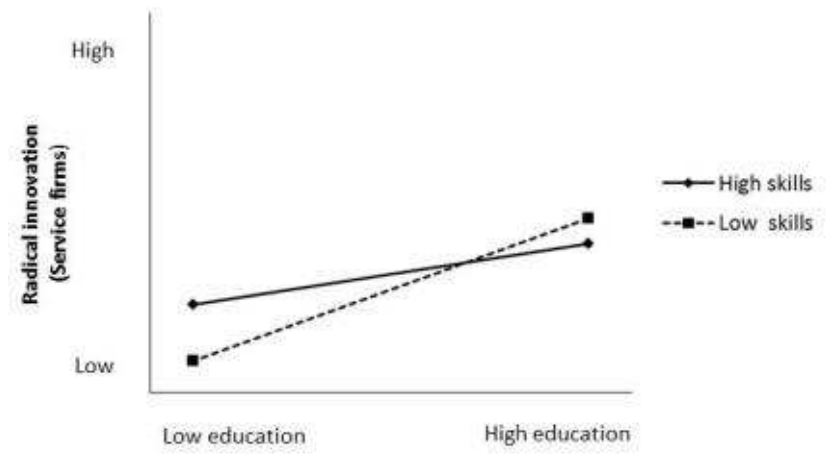

c) Radical service innovation 
Figure 3. Moderating role of gender diversity on the education diversity-innovation performance relationship

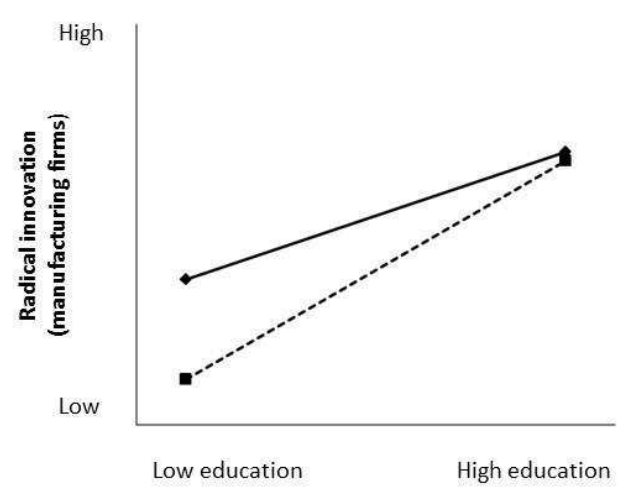

a) Radical manufacturing innovation

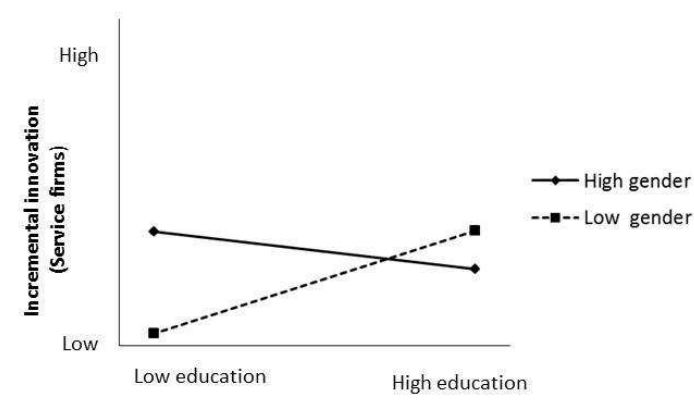

b) Incremental service innovation

Figure 4. Moderating role of gender diversity on the skills diversity-innovation performance relationship

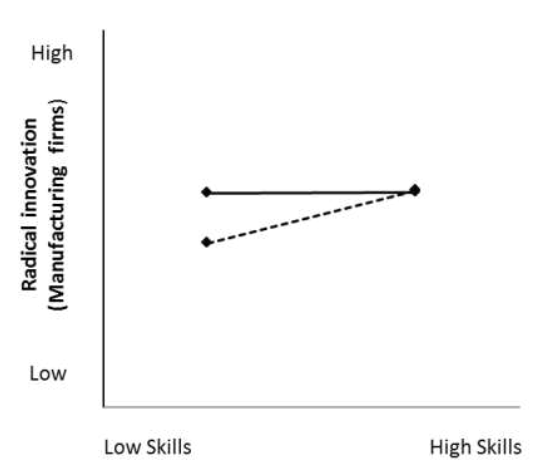

a) Radical manufacturing innovation

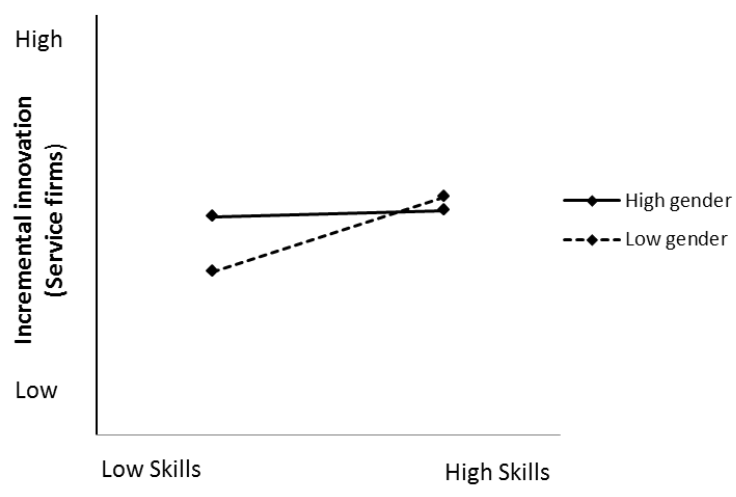

b) Incremental service innovation 